\title{
Eugenics row inflames vote on faculty name
}

Paris. The University of Claude Bernard in Lyons, France, is to vote on a controversial motion to remove posthumously from its faculty of medicine the name of Alexis Carrel, winner of the Nobel prize for physiology or medicine in 1912, following new evidence that he may have belonged to France's main fascist party around the Second World War.

Carrel's prominent role in the eugenics movement, in particular in the United States before the war, is no secret. But the winner of the Nobel prize for work on organ transplantation and cell culture is now alleged also to have been a member of the Parti Populaire Français (PPF).

The university council will vote on the issue before the end of the year. But the debate extends far beyond the naming of the faculty. The combination of France's pride in one of its most distinguished scientists, soul-searching over its collaboration with the Nazis, and current concern over extreme right-wing nationalism, makes an explosive cocktail that is dividing historians, political groups and the university itself.

The most recent allegations were made last month by Golias, a magazine published by progressive Roman Catholics, which reproduced a 1938 issue of the PPF's weekly newspaper L'Emancipation nationale with Carrel's name at the top of a list of intellectuals described as party members. Golias and several human rights organizations have issued a joint statement calling for Carrel's name to be removed from the faculty. The magazine and its supporters ask whether it is "acceptable and moral" that students taking the Hippocratic oath should train under the patronage of a man affiliated with a "racist, anti-Semitic and xenophobic" party.

Their call has been "completely supported" by the French socialist party, according to Jean-Vincent Jihanno, a party spokesman. Jihanno says that the socialists on Lyons city council will also seek to have Carrel's name removed from a Lyons street. The extreme right-wing National Front, however, opposes changing the name of the faculty.

Three years ago, the university set up a commission to investigate Carrel's past, following concern about his role in the eugenics movement. Later the same year, a majority of the university council voted to remove Carrel's name from the faculty, but failed to obtain the necessary absolute majority.

Nevertheless, the university subsequently issued a statement denouncing Carrel's eugenic ideas, and added a suffix to the plaque outside the faculty emphasizing that he was being honoured "exclusively" for his Nobel prize and contribution to medicine.

The compromise reflected a sentiment the commission shared with many scientists, namely that patronage honours the scientific work of an individual without necessarily holding them up as paragons of social behaviour. The commission also noted that renaming the faculty would set a precedent that could require the renaming of streets and buildings named after such illustrious figures as Voltaire, Blaise Pascal or even Louis Pasteur, who in 1884 proposed to the Emperor of Brazil that condemned prisoners be used for testing a rabies vaccine and the effects of cholera bacillus.

The university denies that the decision to give its council another vote on the naming of the faculty has been prompted by the

\section{IMAGE UNAVAILABLE FOR COPYRIGHT REASONS}

Carrel: a Nazi collaborator, or an apolitical scientist reflecting the views of his time?

latest allegations, arguing that it merely follows a "review" of the issue. But human rights organizations, pointing out that this review has been under way for three years, claim that the university has been trying to "bury the dossier".

These organizations argue that the university should review the commission's 1992 conclusion that, though a Pétainiste, Carrel was neither a member of a political party, nor a collaborator. The new evidence, they say, refutes the claim that Carrel was merely a scientist with no political ties.

Carrel - who at 39 was then the youngest-ever recipient of the Nobel prize - received the award shortly after moving from Lyons to the Rockefeller Institute in New York. He later became involved in the US eugenics movement.

In 1935, three years before he returned to France, Carrel published L'Homme cet inconnu ("Man, that unknown"), a book that proposed a eugenicist blueprint for replacing democracy with a 'biocracy' and warned that medical progress risked degenerating 'the great white race' by promoting the survival of the weak, and a consequent increase in mental illness and criminality. The book was translated into 19 languages.

According to Philippe Videlier, a historian at the Centre National de la Recherche Scientifique (CNRS) in Lyons, the latest allegations demonstrate a firm link between Carrel's eugenic and racist theses and the policies of the collaborationist regime of Vichy, which handed over 80,000 French Jews to the Nazis. "Carrel was in phase with, and representative of, Vichy, and vice versa," he claims.

Indeed, Marshal Philippe Pétain, the head of the Vichy regime, met Carrel in 1941, and subsequently provided him with FF40 million to set up the so-called French Foundation for the Study of Human Problems. The university commission concluded that the aim of this foundation - which was dissolved after the liberation of Paris in August 1944, a few months before Carrel's death - was to "prepare a profound reform of French and Western civilization, by creating an élite of researchers to study biological, moral and political problems".

Nonetheless, the significance of Carrel's links with the Vichy government remain hotly contested. Alain Drouard, for example, a CNRS historian at the Centre Roland Mousnier in Paris, and an authority on Carrel, maintains that although Carrel had a political agenda, it was independent of that of the Vichy regime. He also points out that Carrel turned down an offer in 1942 to become secretary of state for health.

Drouard also argues that although Carrel may have attended PPF meetings, the 1938 claim by the PPF's newspaper is not formal proof of Carrel's membership of the party. Carrel belonged to no political party, asserts Drouard, who was a member of the university commission set up to investigate Carrel.

"It's too easy to say Carrel equals Vichy, equals Nazism", says Drouard, claiming that Carrel's views have been taken out of their historical context, in particular the widespread support for eugenic ideas among scientists in the 1930s.

For example, Carrel recommended that criminals - from armed robbers to those who had "seriously abused public confidence" - could be "economically and humanely eliminated" in a "euthanasia establishment equipped with an appropriate gas”. Opponents of Carrel argue that this anticipated the Nazi gas chambers. But Drouard claims Carrel was only proposing a widening - "albeit extreme" - of the grounds for capital punishment.

Drouard's general arguments are supported by Gérard Fontaine, the vice-chancellor of the university. Fontaine says that whereas he originally favoured changing the name of the faculty, he has since changed his mind. "It would be too easy to simply concede to public opinion," he says. "A university's job is to reflect in serenity [on the historical facts]."

But human rights organizations argue that the debate is far from academic. They point out that Carrel's theses have been revived in publications of the extreme right wing French National Front party. Maintaining his patronage of the faculty implicitly lends credibility to the policies of the National Front, they argue. Declan Butler 